\title{
Cynomolgus Maritius Monkey
}

National Cancer Institute

\section{Source}

National Cancer Institute. Cynomolgus Maritius Monkey. NCI Thesaurus. Code C77113.

A medium-sized macaque that tends to be an opportunistic omnivore, the Macaca fascicularis has grey-brown or reddish-brown fur that lightens ventrally, and cheek whiskers. This macaque also has forward directed eyes that allow for binocular vision. The cynomolgus monkey is most commonly utilized in the pre-clinical setting for neuroscience pre-clinical research and has also been shown to be a reservoir for the Ebola virus, monkey pox, and B-virus. Nafovanny is the largest captive breeder and supplier of cynomolgus monkeys to the biomedical research community. 